\title{
Pemanfaatan Sistem Informasi Geografis Untuk Zonasi Kawasan Pertambangan Kabupaten Ngawi
}

\author{
(The Use Of Geographic Information Systems For The Regency's Ngawi Mining Area)
}

\author{
Yazid Fanani ${ }^{1}$, Avellyn Shinthya Sari ${ }^{1}$ \\ ${ }^{1}$ Teknik Pertambangan, Institut Teknologi Adhi Tama Surabaya \\ e-mail: yazid.tambang@itats.ac.id
}

\begin{abstract}
Ngawi regency has large potential of mining resources. However, there is no detailed data in mining area regulation to optimalization of mining resources in Ngawi Regency. This research focus to identify mining resources in Ngawi Regency and making mining zonation used GIS aplication. Ngawi Regency Mining zonation make with weighting and scoring in mining parameters than processing with overlay method. Based on this research, Ngawi has 6 potential distribution mining resources, tehre is : Clay, Andesite, Limestone, Hard Soil, Sandstone, and Breccia. In Mining Parameters Ngawi Regency have 9 Parameters. Ngawi regency mining zonation can be divided into can be permitted to mined in 197 location, can be permitted to mined with certain condition in 91 location, and can't be permitted to mined in 254 location.
\end{abstract}

Keywords: Mining area, mining resources, zoantion.

\section{Pendahuluan}

Kabupaten Ngawi dalam lingkup pengelolaan pertambangan menjadi penting dan strategis karena mempunyai potensi bahan tambang yang cukup besar untuk mendukung pembangunan infrastruktur di Provinsi Jawa Timur yang terus meningkat. Hanya saja sampai saat ini belum ada zonasi untuk kawasan pertambangan yang dapat digunakan dalam optimalisasi pengelolaan dan pemanfaatan potensi bahan galian yang ada.

Belum adanya Zonasi Kawasan Pertambangan di Kabupaten Ngawi dapat mengakibatkan timbulnya konflik kepentingan dalam hal penggunaan lahan karena bahan galian umumnya berada di bawah permukaan tanah dan wilayah pertambangan yang belum dialokasikan ruangnya secara khusus dalam rencana tata ruang wilayah.

\footnotetext{
* Korespodensi Penulis: (Yazid Fanani) Jurusan Teknik Pertambangan,, Universitas Bangka Belitung, Institut Teknologi Adhi Tama Surabaya. E-mail: yazid.tambang@itats.ac.id
}

Oleh sebab itu perlu dilakukan zonasi kawasan pertambangan guna mengetahui potensi dan model penyebaran bahan galian secara komprehensif sebagai parameter dapat atau tidaknya potensi bahan galian untuk diberi izin usaha pertambangan.

Sistem Informasi Geografis telah diaplikasikan dalam pembuatan zonasi kawasan Pertambangan yaitu pada zonasi kawasan pertambangan Kabupaten Waropen [1] dan zonasi kawasan pertambangan Majenang-Bantarkawung [2].

Zonasi kawasan pertambangan Kabupaten Ngawi dilakukan dengan memberikan pembobotan (weighting) dan penilaian (scoring) pada parameterparameter penentuan zonasi pertambangan yang dikerjakan dengan metode pertampalan (overlay) dengan menggunakan software pengolah data spasial. Hasil dari zonasi kawasan pertambangan adalah penentuan zona dapat diberi izin usaha pertambangan, dapat diberi izin usaha pertambangan bersyarat, dan tidak dapat diberi izin usaha pertambangan. Zonasi kawasan pertambangan dapat digunakan sebagai masukan bagi pemerintah daerah 
dalam mengembangkan Rencana Tata Ruang Wilayah (RTRW) dan memudahkan para investor melakukan investasi bidang pertambangan di Kabupaten Ngawi.

\section{Tinjauan Pustaka}

Sistem Informasi Geografis (SIG)

Sistem Informasi Geografis (SIG) merupakan sistem yang berbasiskan komputer untuk menyimpan dan memanipulasi informasi geografis. SIG dirancang untuk mengumpulkan, menyimpan, dan menganalisis objek dan fenomena dimana lokasi geografis merupakan karakteristik penting atau kritis untuk dianalisis. Dengan demikian, SIG merupakan sistem komputer yang memiliki empat kemampuan dalam menangani data yang bereferensi geografis yaitu masukan data, manajemen data, analisis dan manipulasi data, serta luaran data [3].

\section{Wilayah Pertambangan}

Wilayah Pertambangan merupakan wilayah yang mempunyai potensi mineral dan atau batubara yang tidak terikat oleh batasan administrasi pemerintahan dan merupakan bagian dari tata ruang nasional. Wilayah Pertambangan ini menjadi landasan bagi penetapan kegiatan pertambangan dan ditetapkan oleh Pemerintah setelah berkoordinasi dengan pemerintah daerah dan berkonsultasi dengan DPR-RI.

Berdasarkan Kepmen ESDM No : 3672 K/30/MEM/2017 tentang penetapan Wilayah Pertambangan Pulau Jawa dan Bali [5], daerah penelitian termasuk dalam Wilayah Pertambangan Mineral Bukan Logam dan atau Batuan.

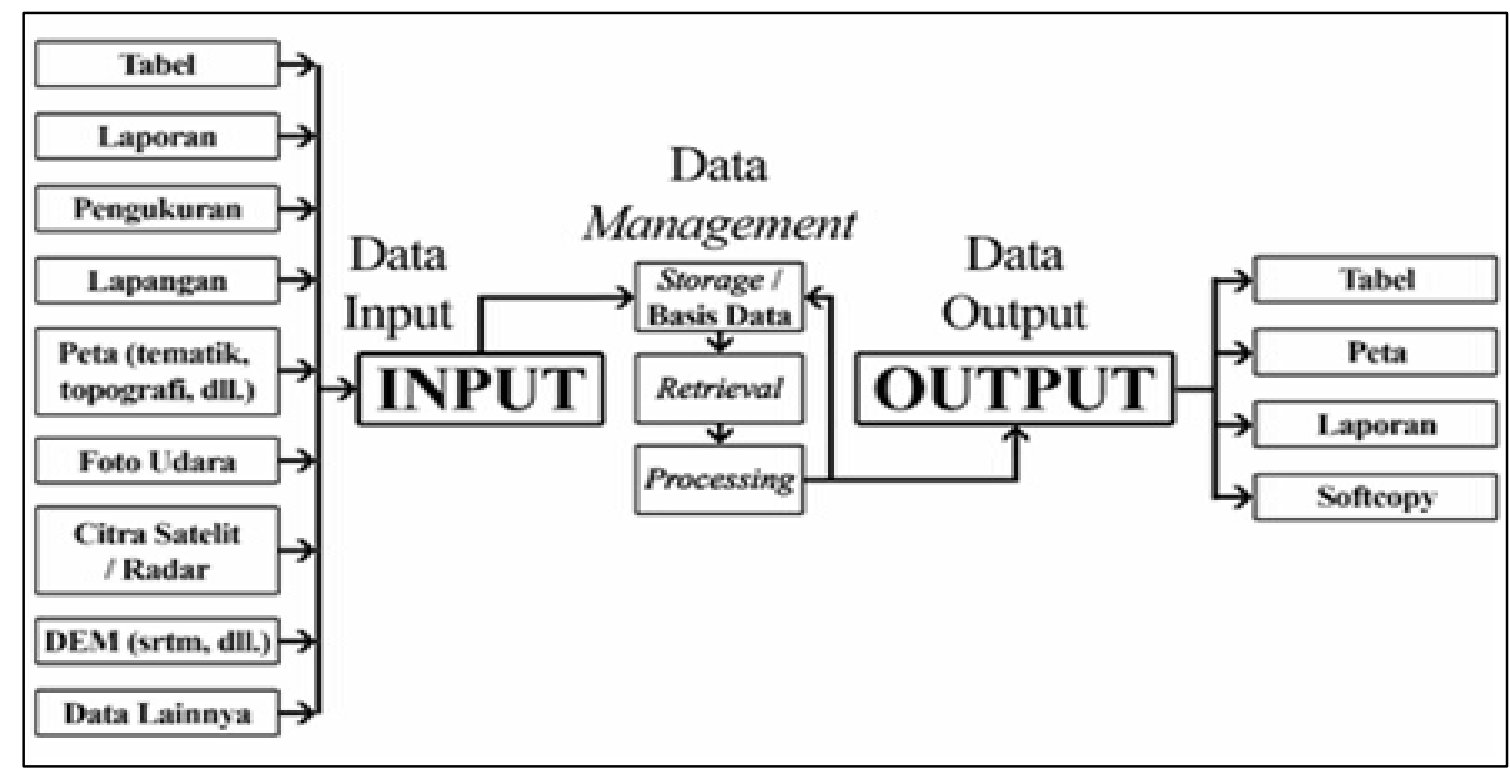

(Sumber : Eddy Prahasta, Sistem Informasi Georafis, 2014, Hal 103)

Gambar 1. Ilustrasi Komponen SIG

Penggolongan Bahan Galian

Penggolongan

bahan

galian

diadasarkan pada UU No. 4 Tahun 2009

Tentang Pertambangan Mineral dan

Batubara [4]. Bahan galian digolongkan

atas : (a) Mineral Radio Aktif; (b) Mineral

Logam; (c) Mineral Bukan Logam; (d)

Batuan; (e) Batubara.
Parameter Penentuan Zonasi Pertambangan

Parameter penentuan zonasi pertambangan merupakan faktor pembatas yang harus ditentukan terlebih dahulu sebelum dilakukan analisa. Parameter tersebut digunakan untuk penentuan prioritas dalam zonasi kawasan pertambangan yang bersumber dari Rencana Tata Ruang Wilayah Kabupaten Ngawi [6]. 
Faktor pembatas dapat dibagi menjadi dua yaitu faktor pembatas internal (Geologi, Hidrogeologi, Lingkungan, Ekonomi) dan faktor pembatas eksternal (Fasilitas Umum, Kebijakan, Kependudukan).

\section{Metode Penelitian}

Penelitian ini dibagi menjadi beberapa tahap, yaitu pengumpulan data, pengolahan data spasial dan penyusunan zonasi kawasan pertambangan. Data penelitian diolah dengan metode pertampalan (overlay) untuk penentuan zonasi kawasan pertambangan yang dapat diberi izin ditambang, dapat diberi izin ditambang dengan bersyarat dan tidak dapat diberi izin ditambang.
Pengolahan data dan penyusunan zonasi kawasan pertambangan menggunakan software pengolah data spasial dan software lain yang menunjang penelitian ini. Penyusunan Zonasi Pertambangan ditentukan dengan pembobotan (weighting) dan penilaian (scoring) didasarkan pada Rencana Tata Ruang Wilayah Kabuapaten Ngawi yang dikerjakan dengan metode pertampalan (overlay). Jumlah total pembobotan (weighing) adalah 1. Pembagian zona dapat diberi izin ditambang, dapat diberi izin ditambang dengan bersyarat dan tidak dapat diberi izin ditambang ditentukan dari total nilai (score) yang didapatkan.

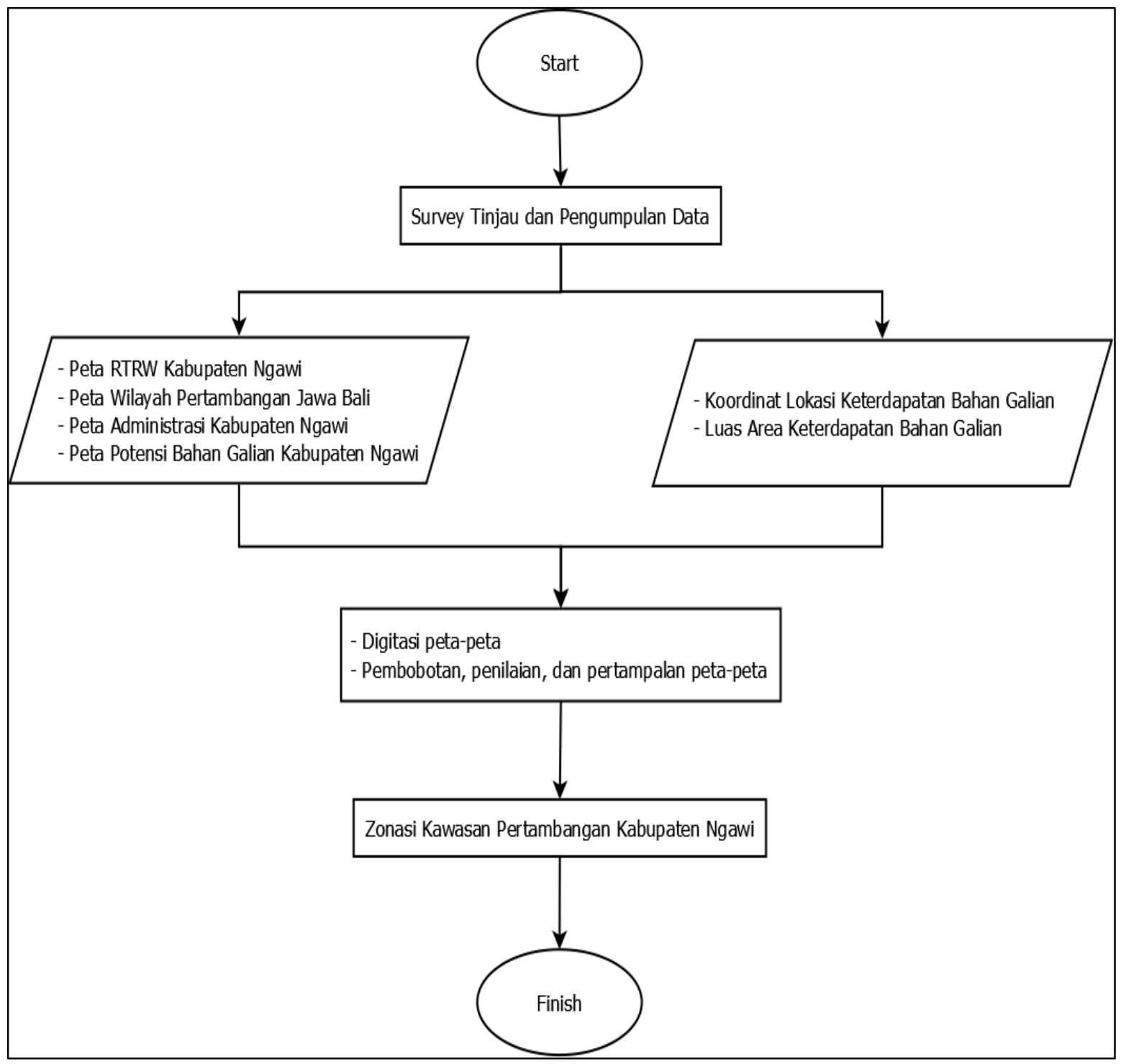

Gambar 2. Diagram Alir Penelitian 
Suatu luasan di permukaan bumi yang telah memenuhi atau tidak bertentangan dengan parameter yang didasarkan pada Rencana Tata Ruang Wilayah Kabuapaten Ngawi, dan merupakan suatu zona yang potensial pengembangan pertambangan dan tidak berdampak negatif terhadap sektor strategis serta didukung seluruh faktor pertimbangan persyaratan, dengan rentang Nilai (score) antara 10 - 15.

\section{Zona Dapat Diberi Izin Ditambang Bersyarat}

Suatu luasan di permukaan bumi yang sebagian sudah memenuhi atau sebagian tidak bertentangan dengan Rencana Tata Ruang Wilayah Kabuapaten Ngawi, dan merupakan suatu zona yang potensial untuk pengembangan pertambangan dengan memperhatikan faktor pertimbangan persyaratan. Zona Dapat diberi izin ditambang Bersyarat ini dengan rentang nilai (score) antara 16-24.

\section{Zona Tidak Dapat Diberi Izin Ditambang}

Suatu luasan di permukaan bumi yang tidak dizinkan dilakukan kegiatan pertambangan "dengan alasan apapun", yang mempunyai rentang nilai (score) $>24$. Hal tersebut mempunyai arti bahwa zona tersebut pada dasarnya tidak dapat dilakukan kegiatan penambangan, tetapi dengan pertimbangan khusus untuk tujuan strategis dan vital maka zona ini dapat dilakukan penambangan. Strategis menyangkut hajat hidup masyarakat banyak, dan vital untuk kestabilan dan keamanan negara.

\section{Hasil Dan Pembahasan}

Potensi Bahan Galian Kabupaten Ngawi

Berdasarkan penelitian, Kabupaten Ngawi memiliki potensi sebaran bahan galian yaitu : Tanah Urug, Andesit, Batugamping, Lempung, Sirtu, dan Breksi. Potensi bahan galian yang paling besar di Kabupaten Ngawi adalah Tanah Urug, Lempung, dan Sirtu. Bahan galian tersebut termasuk kedalam golongan mineral bukan logam dan batuan.
Tabel 1. Sebaran Potensi Bahan Galian Kabupaten Ngawi

\begin{tabular}{lrlr} 
No. & $\begin{array}{r}\text { BAHAN } \\
\text { GALIAN }\end{array}$ & \multicolumn{1}{c}{ LOKASI } & $\begin{array}{c}\text { LUAS } \\
\text { (Ha) }\end{array}$ \\
\hline \multirow{3}{*}{ Andesit } & $\begin{array}{l}\text { Karanganyar, } \\
\text { Kedunggalar, } \\
\text { Mantingan, Pitu, } \\
\text { Widodaren }\end{array}$ & 1.626 \\
& $\begin{array}{l}\text { Bringin, Geneng, } \\
\text { Gerih, Jogorogo, }\end{array}$
\end{tabular}

Karanganyar,

Karangjati,

Kasreman,

Tanah Urug Kedunggalar,

74.779

Mantingan,

Kendal, Ngawi,

Ngrambe,

Padas, Pitu, Sine, Widodaren

Bringin,

Karanganyar,

Karangjati,

Kasreman,

Kedunggalar,

Mantingan,

Ngawi, Padas,

Pitu, Widodaren

Bringin,

Genenng, Gerih,

Karangjati,

Kasreman,

Lempung Kedunggalar,

Kwadungan,

Ngawi, Padas,

Pangkur, Paron,

Pitu

Bringin, Jogorogo,

Karanganyar,

Karangjati,

Kasreman,

Kedunggalar,

Kendal,

Mantingan,

Ngawi,

Ngrambe,

Padas, Paron,

Pitu, Sine,

Widodaren

Bringin,

Karangjati,

$6 \quad$ Breksi Kasreman,

$5.210,70$

Ngawi, Padas,

Pitu 
Parameter Zonasi Kawasan Pertambangan

Berdasarkan evaluasi dari Rencana Tata Ruang Wilayah Kabupaten Ngawi, didapatkan 9 parameter yang menentukan dalam penyusunan Zonasi Kawasan Pertambangan Kabupaten Ngawi.
Parameter tersebut adalah Ketinggian lahan, Kemiringan Lahan, Rawan Bencana Tanah Gerak, Sungai dan Bangunan, Air Tanah, Penggunaan Lahan Pertanian, Mata Air dan Peresapan Air, Hutan dan Perkebuanan, dan Permukiman.Parameter Zonasi Kawasan Pertambangan Kabupaten Ngawi (Tabel 2).

Tabel 2. Parameter Zonasi Kawasan Pertambangan Kabupaten Ngawi

\begin{tabular}{|c|c|c|c|c|}
\hline Parameter & Unsur Penilaian Parameter & Rank & Weight & Score \\
\hline \multirow{3}{*}{$\begin{array}{l}\text { Ketinggian } \\
\text { Lahan }\end{array}$} & - Ketinggian lebih dari $2000 \mathrm{~m}$ dpl & 30 & \multirow{3}{*}{0,10} & 3,0 \\
\hline & - Ketinggian antara $1000-2000 \mathrm{~m}$ dpl & 20 & & 2,0 \\
\hline & - Ketinggian kurang dari $1000 \mathrm{~m}$ dpl & 10 & & 1,0 \\
\hline \multirow{3}{*}{$\begin{array}{l}\text { Kemiringan } \\
\text { Lahan }\end{array}$} & - Kemiringan lebih dari $100 \%$ & 30 & \multirow{3}{*}{0,10} & 3,0 \\
\hline & - Kemiringan antara $50-100 \%$ & 20 & & 2,0 \\
\hline & - Kemiringan kurang dari $50 \%$ & 10 & & 1,0 \\
\hline \multirow{3}{*}{$\begin{array}{l}\text { Rawan Bencana } \\
\text { Longsor }\end{array}$} & - Kawasan Rawan Bencana III & 30 & \multirow{3}{*}{0,10} & 3,0 \\
\hline & - Kawasan Rawan Bencana II & 20 & & 2,0 \\
\hline & - Kawasan Rawan Bencana I & 10 & & 1,0 \\
\hline \multirow{3}{*}{ Air tanah } & - Kedalaman muka air tanah $<5 \mathrm{~m}$ & 30 & \multirow{3}{*}{0,10} & 3,0 \\
\hline & - Kedalaman muka air tanah $5-15 \mathrm{~m}$ & 20 & & 2,0 \\
\hline & - Kedalaman muka air tanah > 15m & 10 & & 1,0 \\
\hline \multirow{5}{*}{$\begin{array}{l}\text { Sungaidan } \\
\text { Bangunan }\end{array}$} & $\begin{array}{l}\text {-Daerah larangan kegiatan } \\
\text { penambangan di tubuh sungai }\end{array}$ & 210 & \multirow{5}{*}{0,10} & 21 \\
\hline & -Pada sempadan sungai $<50 \mathrm{~m}$ dan antara & 30 & & 3,0 \\
\hline & - Di luar sempadan sungai $50-75 \mathrm{~m}$, di & & & \\
\hline & luar jarak $500 \mathrm{~m}$ ke hulu dan $1000 \mathrm{~m}$ ke & 20 & & 2,0 \\
\hline & $\begin{array}{l}\text { - Di luar sempadan sungai }>75 \mathrm{~m} \text { dan } \\
\text { diluar jarak } 500 \mathrm{~m} \text { ke hulu dan } 1000 \mathrm{~m} \text { ke } \\
\text { hilir }\end{array}$ & 10 & & 1,0 \\
\hline \multirow{3}{*}{$\begin{array}{l}\text { Mata Air dan } \\
\text { Peresapan air }\end{array}$} & - Jarak sampai $500 \mathrm{~m}$ di atas mata air & 30 & \multirow{3}{*}{0,10} & 3,0 \\
\hline & - Jarak $>500 \mathrm{~m}$ di atas mata air & 20 & & 2,0 \\
\hline & - Disamping dan dibawah mata air & 10 & & 1,0 \\
\hline \multirow{4}{*}{$\begin{array}{l}\text { Hutan dan } \\
\text { Perkebunan }\end{array}$} & $\begin{array}{l}\text { - Hutan lindung dan atau Kawasan } \\
\text { Lindung }\end{array}$ & 210 & \multirow{4}{*}{0,10} & 21 \\
\hline & - Perkebunan dan atau Hutan rakyat & 30 & & 3,0 \\
\hline & - Hutan produksi & 20 & & 2,0 \\
\hline & - Lahan lainnya & 10 & & 1,0 \\
\hline \multirow{5}{*}{ Permukiman } & - Pada radius $<50 \mathrm{~m}$ & 210 & \multirow{5}{*}{0,20} & 420 \\
\hline & - Pada radius $>50 \mathrm{~m}-1 \mathrm{~km}$ dan dirasa & 30 & & 6,0 \\
\hline & terpengaruh & & & \\
\hline & $\begin{array}{l}\text { - Pada radius }>50 \mathrm{~m}-1 \mathrm{~km} \text { dan tidak } \\
\text { terpengaruh }\end{array}$ & 20 & & 4,0 \\
\hline & - Di luar radius $1 \mathrm{~km}$ & 10 & & 2,0 \\
\hline \multirow{4}{*}{$\begin{array}{l}\text { Penggunaan } \\
\text { lahan Pertanian }\end{array}$} & - Sawah irigasi teknis dan $1 / 2$ telnis & 210 & \multirow{4}{*}{0,10} & 21 \\
\hline & - Sawah irigasi non teknis & 30 & & $\mathbf{3 , 0}$ \\
\hline & $\begin{array}{l}\text { - Sawah tadah hujan, kebun, ladang dan } \\
\text { tegalan }\end{array}$ & 20 & & 2,0 \\
\hline & - Semak belukar dan rerumputan & 10 & & 1,0 \\
\hline \multicolumn{2}{|c|}{ Total pembobotan (weighting) penilaian parameter } & \multicolumn{3}{|c|}{1,00} \\
\hline
\end{tabular}


Zonasi Kawasan Pertambangan Kabupaten Ngawi

Zonasi Kawasan Pertambangan Kabupaten Ngawi dibagi dalam tiga zona, yaitu Zona dapat diberi izin ditambang, Zona dapat diberi izin ditambang dengan bersyarat dan Zona tidak dapat diberi izin ditambang yang ditentukan berdasarkan total nilai (score) dari parameter zonasi dan overlay potensi bahan galian dalam wilayah administrasi Kabupaten Ngawi. berada di Kecamatan Padas, 9 lokasi berada di Kecamatan Pangkur, 10 lokasi berada di kecamatan Pitu, 12 lokasi pada Kecamatan Karanganyar, 7 lokasi pada Kecamatan Mantingan, 14 lokasi pada Kecamatan Kedunggalar, 15 lokasi pada Kecamatan Paron, 14 lokasi pada Kecamatan Ngrambe, 15 lokasi pada Kecamatan Sine, 9 lokasi pada Kecamatan Kendal, dan 11 lokasi pada Kecamatan Jogorogo.

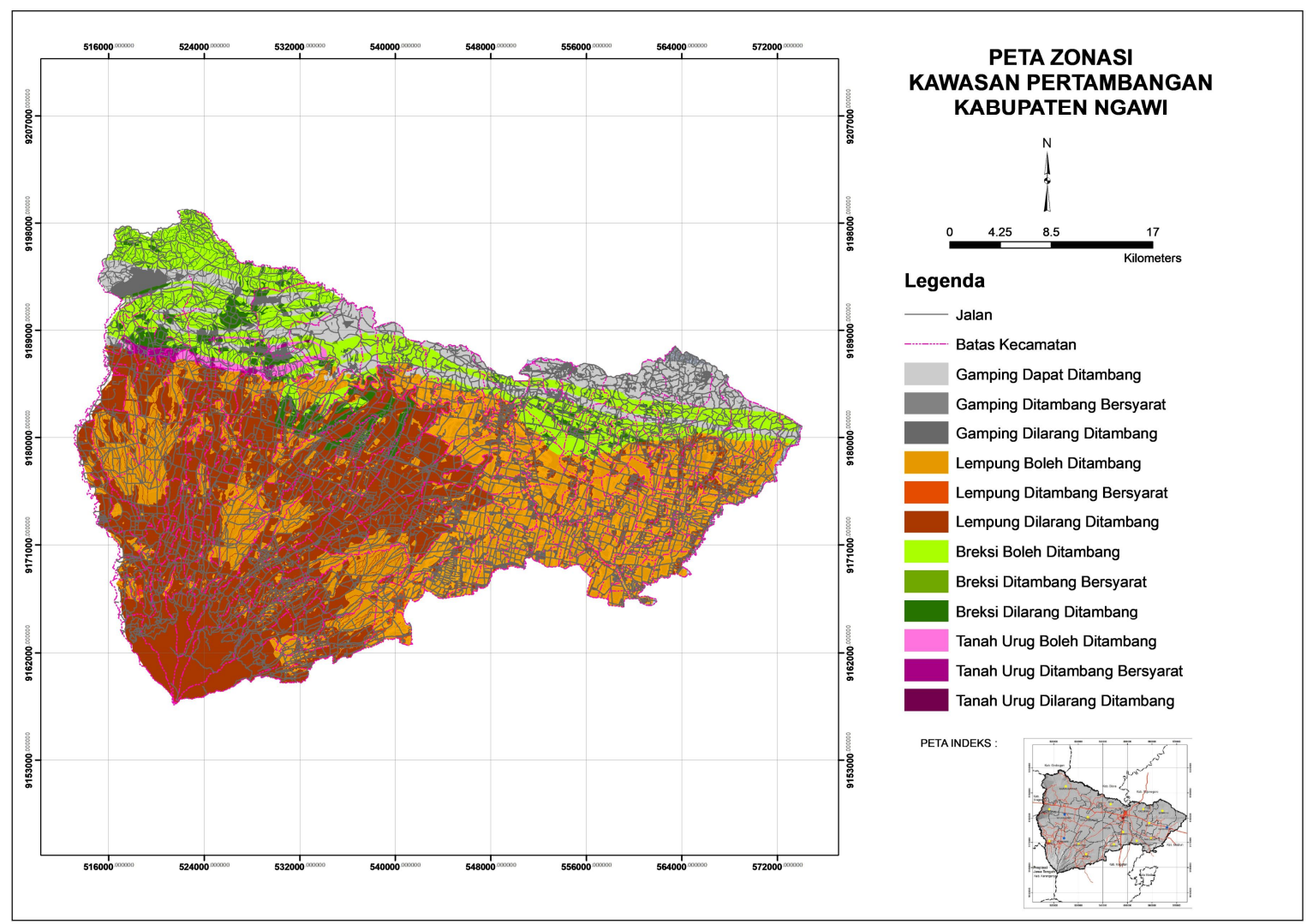

Gambar 3. Peta Zonasi Kawasan Pertambangan Kabupaten Ngawi

Berdasarkan peta zonasi kawasan pertambangan Kabupaten Ngawi maka ditetapkan zonasi pertambangan di masingmasing kawasan sebagai berikut :

\section{Zona Dapat Diberi Izin Ditambang}

Zona dapat di beri izin usaha pertambangan memiliki 197 lokasi yang tersebar di beberapa daerah. Dengan 6 lokasi berada di Kecamatan Bringin, 12 lokasi berada di Kecamatan Geneng, 4 lokasi berada di Kecamatan Gerih, 17 lokasi berada di Kecamatan Karangjati, 14 lokasi berada di Kecamatan Kwadungan, 13 lokasi berada di Kecamatan Ngawi, 15 lokasi
Zona Dapat Diberi Izin Ditambang Bersyarat

Zona dapat diberi izin usaha pertambangan bersyarat memiliki 91 lokasi yang tersebar di beberapa daerah. 8 lokasi berada di Kecamatan Bringin, 13 lokasi berada di Kecamatan Geneng, 4 lokasi berada di Kecamatan Gerih, 15 lokasi berada di Kecamatan Karangjati, 9 lokasi berada di Kecamatan Kwadungan, 11 lokasi berada di Kecamatan Ngawi, 13 lokasi berada di Kecamatan Padas, 9 lokasi berada di Kecamatan Pangkur, dan 9 lokasi berada di kecamatan Pitu. 
Zona Tidak Dapat Diberi Izin Ditambang

Zona tidak dapat diberi izin usaha pertambangan memiliki 254 lokasi yang tersebar di beberapa daerah dengan 8 lokasi berada di Kecamatan Bringin, 13 lokasi berada di Kecamatan Geneng, 4 lokasi berada di Kecamatan Gerih, 15 lokasi berada di Kecamatan Karangjati, 14 lokasi berada di Kecamatan Kwadungan, 9 lokasi berada di Kecamatan Ngawi, 19 lokasi berada di Kecamatan Padas, 9 lokasi berada di Kecamatan Pangkur, 15 lokasi berada di kecamatan Pitu, 29 lokasi pada Kecamatan Karanganya, 24 lokasi pada Kecamatan Mantingan, 28 lokasi pada Kecamatan Kedunggalar, 18 lokasi pada Kecamatan Paron, 14 lokasi pada Kecamatan Ngrambe, 15 lokasi pada Kecamatan Sine, 9 lokasi pada Kecamatan Kendal, dan 11 lokasi pada Kecamatan Jogorogo.

\section{Kesimpulan}

Kabupaten Ngawi memiliki 6 potensi sebaran bahan galian yaitu : Tanah Urug, Andesit, Batugamping, Lempung, Sirtu, dan Breksi yang tersebar di wilayah administrasi Kabupaten Ngawi. Pada wilayah administrasi Kabupaten Ngawi terdapat 9 parameter yang berpengaruh terhadap Zonasi Kawasan Pertambangan. Parameterparameter tersebut disusun berdasarkan Rencana Tata Ruang Wilayah Kabupaten Ngawi. Berdasarkan dari 9 parameter yang berpengaruh dan sebaran potensi bahan galian, Zonasi Kawasan Pertambangan Kabupaten Ngawi dibagi kedalam 3 zona yaitu Zona Dapat Diberi Izin Ditambang yang terdapat pada 197 lokasi , Zona Dapat Diberi Izin Ditambang Bersyarat pada 91 lokasi, dan Zona Tidak Dapat Diberi Izin Ditambang sebanyak 254 lokasi. Zona yang paling luas di Kabupaten Ngawi adalah Zona yang tidak dapat diberi izin ditambang. Hal ini disebabkan cukup padatnya kawasan permukiman di Kabupaten Ngawi sehingga lokasi permukiman relatif dekat dengan daerah potensi bahan galian.

\section{Ucapan Terima Kasih}

Sehubungan dengan penelitian ini, kami tim peneliti mengucapkan terima kasih yang sebesar-besarnya kepada DRPM DIKTI, LPPM ITATS, BANKESBANGPOL Provinsi Jawa Timur dan BAPPEDA Kabupaten Ngawi atas segala bantuan dalam pelaksaan kegiatan penelitian ini.

\section{Daftar Pustaka}

[1] Bargawa, Waterman S. dan Isak S.A., Victor. 2015. "Model Zonasi Untuk Kawasan Pertambangan Mineral Logam Dan Batubara (Studi Kasus Kabupaten Waropen Provinsi Papua)". PROCEEDING, SEMINAR NASIONAL KEBUMIAN KE-8 AcademiaIndustry Linkage 15-16 OKTOBER 2015. GRAHA SABHA PRAMANA.

[2] Fanani, Yazid. 2016. "Aplikasi Sistem Informasi Geografis Untuk Zonasi Kawasan Pertambangan Majenang-Bantarkawung". Jurnal PROMINE, Vol. 4 No.2.

[3] Prahasta, Eddy. 2009. "Sistem Informasi Geografis : Konsep-konsep Dasar (Perspektif Geodesi dan Geomatika)". Informatika. Bandung.

[4] Pemerintah Indonesia. 2009. "Undangundang No.4 Tahun 2009 tentang Pertambangan Mineral dan Batubara". Sekretariat Negara. Jakarta.

[5] P. N. Kementerian. 2017. "Kepmen ESDM No : 3672 K/30/MEM/2017 tentang Penetapan Wilayah Pertambangan Pulau Jawa dan Bali". Sekretariat Negara. Jakarta.

[6] Pemerintah Kabupaten Ngawi. 2010. "Peraturan Daerah Kabupaten Ngawi No. 10 Tahun 2011 Tentang Rencana Tata Ruang Wilayah Kabupaten Ngawi". 